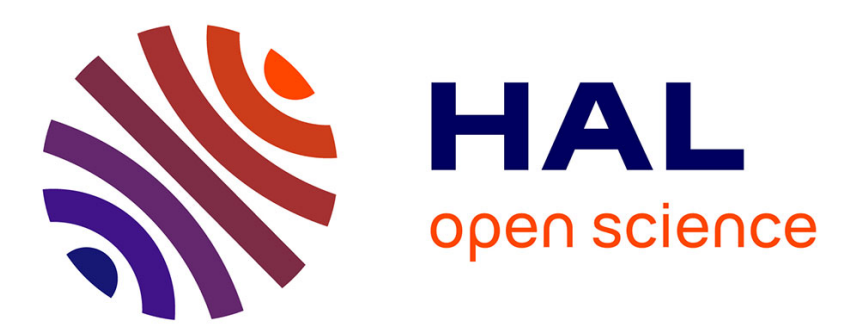

\title{
Genetically modified glyphosate-tolerant soybean in the USA: adoption factors, impacts and prospects. A review Sylvie Bonny
}

\section{To cite this version:}

Sylvie Bonny. Genetically modified glyphosate-tolerant soybean in the USA: adoption factors, impacts and prospects. A review. Agronomy for Sustainable Development, 2008, 28 (1), pp.1-12. 10.1051/agro:2007044 . hal-01186913

\section{HAL Id: hal-01186913 \\ https://hal.science/hal-01186913}

Submitted on 31 May 2020

HAL is a multi-disciplinary open access archive for the deposit and dissemination of scientific research documents, whether they are published or not. The documents may come from teaching and research institutions in France or abroad, or from public or private research centers.
L'archive ouverte pluridisciplinaire HAL, est destinée au dépôt et à la diffusion de documents scientifiques de niveau recherche, publiés ou non, émanant des établissements d'enseignement et de recherche français ou étrangers, des laboratoires publics ou privés. 


\title{
Genetically modified glyphosate-tolerant soybean in the USA: adoption factors, impacts and prospects. A review
}

\author{
Sylvie BONNY* \\ INRA, UMR Économie publique, BP 1, Campus de Grignon, 78850 GRIGNON, France
}

(Accepted 10 September 2007)

\begin{abstract}
Transgenic crops are the subject of lively debate and controversy. Despite such controversy, transgenic soybean has undergone a rapid expansion. Among various types of transgenic crops, herbicide-tolerant crops appear to many to be of limited interest, especially in Europe. Nonetheless, herbicide-tolerant crops are the most widely spread in the world. Indeed, glyphosate-tolerant soybean was notably the most cultivated transgenic plant in the world in 2006. In the USA 91\% of soybean was transgenic in 2007. How can this particularly significant diffusion in the USA be explained, and what are its impacts? Such issues are addressed in this article, using surveys, studies of numerous statistical data and literature analysis. A first section underlines the importance of soybean in the current development of transgenic crops in the world, and the favourable context for their expansion in the USA. Then follows an analysis of the advantages and drawbacks of transgenic soybean for American farmers. Factors explaining the rapid diffusion of transgenic soybean are also analysed. A comparison of transgenic versus conventional soybean reveals that transgenic glyphosate-tolerant soybean allows both the simplification of weed control and greater work flexibility. Cropping transgenic soybean also fits well with conservation tillage. Transgenic soybean has an economic margin similar to conventional soybean, despite a higher seed cost. The next section describes the evolution of the use of herbicides with transgenic soybean, and some issues linked to the rapid increase in the use of glyphosate. At the beginning a smaller amount of herbicides was used, but this amount increased from 2002, though not steadily. Nonetheless, the environmental and toxicological impacts of pesticides do not only depend on the amounts applied. They also depend on the conditions of use and the levels of toxicity and ecotoxicity. The levels of ecotoxicity seem to have somewhat decreased. The success of transgenic soybeans for farmers has led to a higher use of glyphosate as a replacement for other herbicides, which has in turn led to a decline in its effectiveness. However, the issue here is not only genetic engineering in itself, but rather the management and governance of this innovation. Finally, the prospects of transgenic soybean are addressed. Transgenic soybean with new traits should be placed on the market. The conclusion describes economic context of the development of the first transgenic crops.
\end{abstract}

transgenic crop / genetically modified crop / soybean / herbicide tolerance / glyphosate / herbicide / agricultural economics / impact / United States

\section{INTRODUCTION ${ }^{1}$}

Transgenic crops are the subject of lively controversy due to the hopes raised by the new traits that can be introduced into plants and the diverse fears they provoke concerning their effects on the environment, health and the economy. The most widespread transgenic crops during the first 12 years of their

* Corresponding author: bonny@grignon.inra.fr

${ }^{1}$ Acronyms used in this article are given below. The terms "transgenic crop" and "genetically modified (GM) crop" are used interchangeably. The current term of "genetically modified organism" (GMO) is also used for transgenics in general.

Acronyms

BT: Bacillus thuringiensis

EIQ: Environmental Impact Quotient

GM: genetically modified

GMO: genetically modified organism

RR: Roundup Readyß

CT: conservation tillage

HT: herbicide-tolerant

EU: European Union

USDA: United States Department of Agriculture

USDA-NASS: USDA National Agricultural Statistics Service

USDA-ERS: USDA Economic Research Service diffusion since 1996 have been tolerant to herbicides, particularly glyphosate. In 2006, this trait was present in $81 \%$ of the surface area of transgenic crops, which represented a total of 102 million hectares. This expansion of herbicide-tolerant (HT) crops seems somewhat surprising as it goes against one of the expectations concerning the applications of biotechnologies. Indeed, it was hoped that the latter would lead to a form of agriculture that enhanced life processes and thus required fewer chemical products. How can this high diffusion be explained, and what are its effects, particularly in terms of the evolution of herbicide use? Among the transgenic crops, one of them, soybean tolerant to glyphosate herbicide, or Roundup Ready® (RR) soybean, stands out due to its particularly high expansion level and the extent of the area it covers. Indeed, it is the most widespread transgenic crop on the planet, representing $57 \%$ of the entire area under transgenic cultivation in 2006. Furthermore, it is the only plant for which a majority (64\% in 2006) of the area cultivated in the world is transgenic; whereas for other crops this proportion is far lower, often non-existent. Finally, in the USA it has been massively adopted.

It therefore seems useful to seek a better understanding of the adoption factors and impacts of glyphosate-tolerant 
soybean, especially since in Europe, transgenic crops are often presented as holding little interest for farmers. In terms of impacts, one question is often asked: how has herbicide use evolved for this transgenic herbicide-tolerant crop? This is one of the points that will be addressed more particularly. Indeed, Western agriculture is often criticised for using too many pesticides, a factor leading to the weak sustainability of its practices. Thus, it is useful to understand better the herbicide consumption of transgenic crops, particularly HT ones. Part of this text will focus on this issue without addressing the other economic or environmental aspects dealt with in other papers (Nelson, 2001; Kalaitzandonakes, 2003; Wesseler, 2005; Duke and Ragsdale, 2005; Gomez-Barbero and Rodriguez-Cerezo, 2006; Sanvido et al., 2007).

An inventory of transgenic crops around the world and in the USA is presented first (II). Then diverse factors at the origin of HT soybean spread in the USA, particularly at an agroeconomic level, are analysed (III). Evolutions in the use of herbicides, and agro-economic and environmental impacts are then studied in more detail (IV). Finally, some prospects of transgenic soybean in the USA are tackled (V).

This paper is based on multiple sources: on the one hand, interviews with American scientists and actors in the agricultural and para-agricultural sector on explicative factors and the impacts of the adoption of HT soybean; on the other hand, scientific articles, symposium papers and agronomic extension newsletters, and finally, the collection, analysis and processing of the different statistical data available. In particular, USDA (US Department of Agriculture) statistical data on the use of different herbicides on soybean-cultivated land from 1990 to 2006 have been analysed in order to pinpoint trends in this matter.

\section{AN UNEVEN EXPANSION OF TRANSGENIC CROPS AROUND THE WORLD AND IN THE USA: THE IMPORTANCE OF HERBICIDE-TOLERANT SOYBEAN}

In mid-2007, 19 transgenic species had each been authorised in at least one (sometimes a single) country for cultivation, human consumption or animal consumption. In total, thirteen types of traits have been introduced into these species by transgenesis: herbicide tolerance, resistance to certain insects or viruses, etc. (Agbios, 2007). However, the number of transgenic species cultivated today on a large scale is much lower than the 19 authorised and their diffusion remains very condensed (Tab. 1). Thus, in 2006, three crops (soybean, corn and cotton) represented by themselves $95 \%$ of the world's GM acreage. Moreover, four countries (the USA, Argentina, Brazil and Canada) totalled $88 \%$ of the world's transgenic crop acreage. One particular trait, tolerance to a herbicide (sometimes associated with another) was present in $81 \%$ of transgenic crops (James, 2007). Meanwhile, for the main plants cultivated throughout the world, the share of transgenic varieties is very low, often non-existent, except for soybean, cotton, canola and corn. Thus, in 2006 on a world scale, the total acreage of transgenic crops (102 million ha) added up to little more than $7 \%$ of all the planet's crops (approximately 1.4 million ha, permanent crops excluded).

In the USA, which accounted for 54\% of the transgenic crops cultivated worldwide in 2006, one crop, HT soybean, has progressed significantly more quickly than the others (Tab. 2). In 2007 , it represented $91 \%$ of the surface area dedicated to soybean cultivation in the USA, and even $97 \%$ in South Dakota and $96 \%$ in Mississippi and Nebraska (USDA NASS, 2007).

There are many factors behind the success of transgenic crops in the USA, and in particular of HT soybean. The development of any innovation in agriculture can generally be explained by a combination of institutional, economic, agronomic, social and cultural factors which it is not possible to analyse in detail here. Very briefly, the rapid development of biotechnology in the USA was favoured by the contextual framework of the country: undeniably, there exists in the USA a firm faith in progress, business and innovation (Bonny, 2005a). Moreover, the legislative process and government policy in the USA are more strongly influenced by lobby groups and less by public opinion than in the EU. In the American approach to regulation, decision-making rests on the one hand on scientific considerations, and on the other on the legal responsibility of the private sector and manufacturers: any problems which might arise will be settled through the courts. Because of this, the expectations placed on state regulation are fewer than in some EU countries. The American situation is also characterised by a rather high level of confidence in the agencies responsible for food safety. Moreover, there is a highly developed level of cooperation between private companies and public research bodies, notably the universities and the USDA Agricultural Research Service; this cooperation involves private companies, farmers and producer associations. Finally, Monsanto, which is behind most of the transgenic crops currently in use, has had effective strategies for rapid market penetration through their thorough knowledge and experience of regulatory approval procedures, through licensing policies ("branded seed "storefront" and broad licensing accelerates market access and trait penetration") and through gene stacking (Monsanto, 2003); the latter, for example, increases the value of seeds as it includes two or three technology fees rather than just one.

Furthermore, at least until recently, biotechnology was generally regarded favourably in the USA, unlike in the EU (Bonny, 2003). There are few inquiries into identical questions that allow a comparison of opinions in the USA and the EU; the surveys that do show a more favourable opinion of GMOs in the USA (Bonny, 2007). This is the case, for example, with the Environics poll in 2000 (FAO, 2004), the Worldviews survey (2002), of certain questions in the Canada-USA polls and the Eurobarometer in 2005 (Canadian Biotechnology Secretariat, 2005; Eurobarometer, 2006). Indeed, in the USA the relationship with food is, in general, often different from that in the EU, with a stronger sensitivity to its practicality and less attachment to local produce. Furthermore, American agriculture is largely orientated towards export and biotechnology is considered to be a competitive factor. 
Table I. Distribution of transgenic crop acreage in the world in 2006 (in million hectares) (From James, 2007).

\begin{tabular}{llllllllc}
\hline By country & $10^{6}$ ha & $\%$ & By crop & $10^{6}$ ha & $\%$ & By transgenic trait & $10^{6}$ ha & $\%$ \\
\hline USA & 54.6 & 53.5 & Soybean & 58.6 & 57 & Herbicide tolerance $(\mathrm{HT})$ & 69.9 & 68 \\
Argentina & 18.0 & 17.7 & Corn & 25.2 & 25 & & 19 & 19 \\
Brazil & 11.5 & 11.3 & Cotton & 13.4 & 13 & Insect resistance $(\mathrm{Bt})$ & \\
Canada & 6.1 & 6.0 & Canola & 4.8 & 5 & & & 13.1 \\
India & 3.8 & 3.7 & Other & $<0.5$ & $<0.5$ & Insect resistance \& herbicide tolerance & 13 \\
China & 3.5 & 3.4 & (squash, & & & & $<0.1$ & $<1$ \\
Paraguay & 2.0 & 2.0 & papaya) & & & Virus resistance or other & \\
South Africa & 1.4 & 1.4 & & & & & $\mathbf{1 0 2}$ & $\mathbf{1 0 0}$ \\
\hline TOTAL & $\mathbf{1 0 2}$ & $\mathbf{1 0 0}$ & Total & $\mathbf{1 0 2}$ & $\mathbf{1 0 0}$ & TOTAL & &
\end{tabular}

HT: herbicide-tolerant; through herbicide tolerance, plants have been genetically modified to tolerate the effects of a broad-spectrum herbicide, such as glyphosate. Bt: variety resistant to some pests through Bacillus thuringiensis toxin (Bt); it is achieved by inserting a gene from the bacteria Bacillus thuringiensis, which creates a toxin that affects some insects.

Table II. Proportion of the main transgenic crops in the USA, 1996 to 2007 (in \% of the total surface of each crop planted) (Source: USDA ERS, 2007a; USDA NASS, 2000-2007).

\begin{tabular}{cccc}
\hline Year & HT soybean & Bt and/or HT Corn & Bt and/or HT cotton \\
\hline 1996 & 7 & 4 & 17 \\
1997 & 17 & 12 & 25 \\
1998 & 37 & 25 & 45 \\
1999 & 47 & 37 & 48 \\
2000 & 54 & 25 & 61 \\
2001 & 68 & 26 & 69 \\
2002 & 75 & 34 & 71 \\
2003 & 81 & 40 & 73 \\
2004 & 85 & 45 & 76 \\
2005 & 87 & 52 & 79 \\
2006 & 89 & 61 & 83 \\
2007 & 91 & 73 & 87 \\
\hline
\end{tabular}

HT: herbicide-tolerant; Bt: variety resistant to some insects through Bt toxin.

Thus, HT soybean has a particular position as it is the most widespread transgenic crop. Furthermore, a very high proportion of soybean cultivated is transgenic. How can this great expansion be explained, particularly in the USA at farm level, beyond the general context that has been rapidly presented?

\section{AGRO-ECONOMIC ADVANTAGES OF HERBICIDE-TOLERANT SOYBEAN FOR US FARMERS}

\subsection{Agro-economic advantages that compensate for the drawbacks}

At the farming level, there are many factors behind the rapid development of HT soybean (Alexander, 2006). Table 3 gives an overview of its advantages and disadvantages, the relative importance of which will differ in each particular situation. One of the principal advantages of HT soybean for farmers comes from the fact that weeding is simplified, at least in the short term. Previously, farmers used several herbicides and some weeds were still difficult to control. Transgenic cultivation allows for easier weed management because only a single product is required. Moreover, the period when weed treatments can be applied is slightly longer, offering greater flexibility of work and diminishing the risk of intervening too late if weather conditions prevent treatment at the appropriate time. Furthermore, the herbicides used previously were in certain cases fairly persistent and could affect subsequent crops and even the soybean itself (UIUC, 1999; Carpenter and Gianessi, 1999, 2000, 2001, 2002; Bullock and Nitsi, 2001; Nelson, 2001; Gianessi et al., 2002).

For farmers, the economic advantage of HT soybean in relation to conventional soybean depends among other things on the difference in margin. The higher cost of transgenic seed - the "technology fee" - is generally balanced out by the reduced cost of herbicides. A comparison of conventional and transgenic soybean shows that they have broadly similar margins, sometimes slightly higher for transgenic soybean. However, various other aspects reinforce the agro-economic advantages of HT soybean for the farmer. These various other agro-economic effects are significant:

- relatively easier weed management and simplified herbicide applications free up time for other activities. This aspect, although hard to quantify, is significant, as the work 
Table III. Assessment elements of the advantages and drawbacks of glyphosate-tolerant soybean.

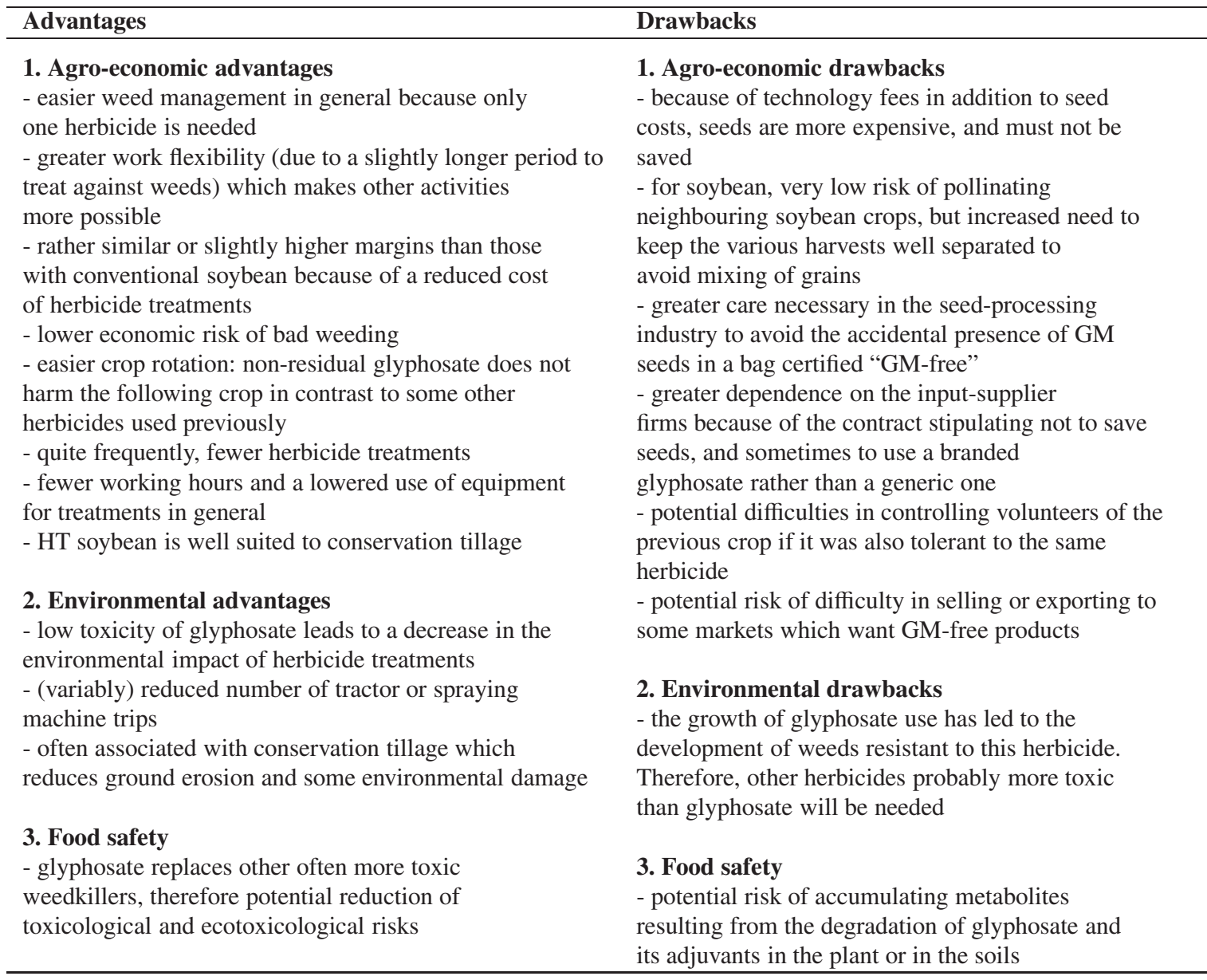

of a farmer consists of multiple tasks which are sometimes in competition with each other at busy times, particularly in cases of multifunctionality or multiactivity. In any case, the time freed is often of important value to farmers (FernandezCornejo et al., 2005; Gardner and Nelson, 2007a).

- Reduced risk of failed weed control: with HT soybean the period when herbicides can be applied is slightly longer, which is an advantage when the weather is bad or where there are large areas to be treated. However, treatments which are applied too late will have an adverse effect on yield (Knezevic et al., 2003; Owen, 2007).

- HT soybean cultivation often goes hand in hand with other techniques such as cultivation in rows sown closer together and the techniques of "conservation tillage" (CT) (Barnes, 2000; Marra et al., 2004; Cerdeira and Duke, 2005). These techniques are being developed because of various programmes to limit erosion and conserve soil: in 1995, $48.6 \%$ of the soybean was cultivated in this way and $61.3 \%$ in 2004 (CTIC, 2004). Several studies underline the good association between conservation tillage and HT crops which allows weed problems previously met with these techniques to be resolved (ASA, 2001). The USDA surveys indeed showed that in 2002, the proportion of CT was higher $(67 \%)$ with GM varieties than with non-GM varieties of soybean $(51 \%)$.

- The contractual agreement not to save seeds for the following year's sowing increases the cost of HT soybean seed. The importance of saving seed varies according to the country and the crop. In the USA, in 1998 15-20\% of soybean cultivation land was sown with seeds saved from the farmer's previous season's harvest and not purchased on the market. In other countries, such as Argentina (a major soybean producer), this figure was as high as 25 to $35 \%$ and was more than doubled by black market purchases from other farmers outside official commercial channels (US GAO, 2000). But the companies took this into account in their pricing policies for GM seeds: thus, in 1998 HT soybean seeds were on sale at much lower prices in Argentina than in the USA. This brought protests from American producers, who felt they were being penalised. For farmers, one of the main questions on the subject is the evolution in price of the technology fee. The evidence of a farmer questioned on the contracts issue sheds some light on the point of view of American farmers.

"Farmers for the most part did not have a problem with the contracts required from Monsanto. They understood the benefits of the program and that Monsanto needed a return on 
their investment. They did not like the ability not to save seed, but farmers were increasingly buying new seed every year before RR technology became available. One of the main issues for not saving seed was the rapid improvement in RR varieties each year. Not only was saving the seed illegal, but you needed to get the best performing genetics on the farm as early as possible. A bushel per acre of increased yield would pay for the new seed. There might actually be more resistance by farmers today to Monsanto's polices because of the increase in the technology fees. (I think they started at \$ 4.00-\$5.00 per bag, and are at \$ 7.00-\$8.00 today). The other issue unpopular with US farmers is the lack of a technology fee charge to farmers in South America. As we see Brazil and Argentina taking a larger share of the global soybean market, farmers are upset that this competition does not have to pay the fees we do. Monsanto has to figure this one out. » (Illinois farmer, personal communication, 2003).

Gene flow between neighbouring crops of conventional soybean and GM soybean does not present any problems. Soybean, which is $99 \%$ autogamous, poses few risks in terms of cross-pollination with neighbouring non-GM crops of the same species, unlike canola and corn. But vigilance is required in a number of different areas, in particular in the seedprocessing industry in order to avoid GM seeds being accidentally mixed with seeds certified as "GM-free", which some farmers choose in order to sell them at a premium in specific markets. Otherwise, there is a risk of tricky questions of liability arising if farmers targeting specific niches in the market were to find that their produce lost its certification as a result of GM seeds being accidentally present in their seed. Downstream, separated channels to preserve identity also exist, where a rigorous separation of batches is necessary (Bullock and Desquilbet, 2002).

\subsection{Transgenic soybean is of variable, quite often positive, economic interest}

The difference in margin between HT and conventional soybean is difficult to quantify as there are wide variations in the cost of soybean production between farms (Foreman and Livezey, 2002) and as there were more than 317,600 farms growing soybean in 2002. Moreover, seed, herbicide and soybean prices have varied over the past few years (Bullock and Nitsi, 2001; Ash, 2001). A lower expenditure on herbicides due to the lower price of glyphosate and less treatments compensates approximately for the extra cost of transgenic seeds (Sankula et al., 2005). Therefore, the cost of GM soybean production is generally similar to or slightly lower and the margin quite often similar to or slightly higher than for conventional soybean. However, the difference between HT and conventional soybean depends on the weeds present and the herbicides (or other means of control) used: for conventional, there is a wide range of possibilities; for transgenic, a certain range also exists - Monsanto proposes several formulations according to the additive type and concentration. In any case, the cost of herbicides was reduced for many farmers whether they used
HT varieties or not, because of a drop in all herbicide prices (see below) (Bullock and Nitsi, 2001).

In order to compare the results of crops cultivated with different production techniques, there is often an attempt to consider the costs of production or the margin in each case. However, this has its limits as the comparison is closely linked to price ratios which can vary quite markedly. It is therefore helpful to complement it with a quantitative analysis of the production factors used. Furthermore, it is important to remember an important point which is often forgotten: the farm must be considered as a system and the analysis of one production in isolation should be avoided. In particular, establishing the production costs of one crop independently of other possible productions and its interaction with the functioning of the whole farm can give a distorted picture as it ignores various opportunity costs. So, we have seen that HT soybean may have other advantages for the producer: simplification of weed control freeing up time for other activities or areas of production, a fair correlation with conservation tillage and hence development of this (synergy effect), non-persistence of herbicides, etc. Finally, micro-economic profitability calculations often ignore longer-term, economic or environmental external costs.

\section{IMPACTS OF THE EXPANSION OF SOYBEAN ON THE USE OF HERBICIDES}

\subsection{Questions on sources and methods}

A controversial point often brought up in Europe concerning GMOs is the evolution in the quantity of pesticides used. Thus, this section focuses on this issue without tackling other economic or environmental aspects. The trends in the use of pesticides with transgenic crops are to be looked at case by case as they vary according to the new trait type introduced, the plant considered, the pedoclimatic conditions and the socio-economic context. With HT soybean, the usual conventional herbicides are for the most part removed and substituted with glyphosate. However, conventional herbicides are used in very variable doses per ha; the recommendations can vary from $10 \mathrm{~g} / \mathrm{ha}$ to $1.3 \mathrm{~kg} / \mathrm{ha}$ according to the molecule, whereas glyphosate is often spread at a dose of approximately $0.75 \mathrm{~kg} / \mathrm{ha}$. So, if, for example, 1.5 glyphosate treatments replace 3 conventional treatments, the assessment of quantity in $\mathrm{kg} / \mathrm{ha}$ would be highly variable according to the weedkillers used previously, but it would not have a significant meaning. A simple evaluation of the quantity of herbicide used before and after the development of transgenic soybean is insufficient. To appreciate their environmental and toxicological impact, it is necessary to balance the level of weedkiller use by taking into account the conditions of application and by using toxicity and ecotoxicity indicators.

To assess the impacts of HT soybean, diverse methodological questions arise. Indeed, a comparison of weedkiller use on GM and non-GM soybean in the same year is not enough because the two cultivated areas can have different characteristics; farmers could use, for example, HT soybean where the 


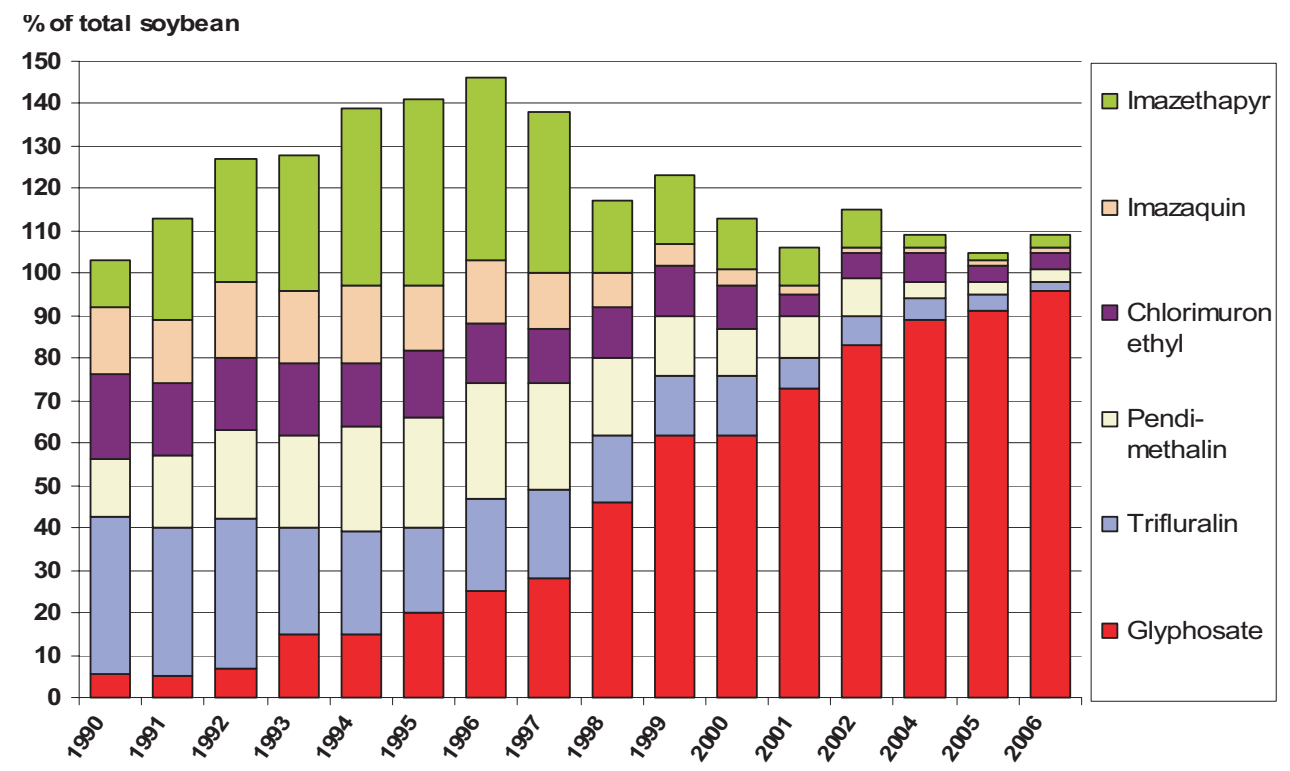

Figure 1. Main herbicides used on total soybean acreage, 1990-2006 (as \% of soybean surface treated by each herbicide) (From USDA NASS, 1991-2007). With the development of glyphosate-tolerant soybean, this herbicide is used far more extensively. Indeed, it replaces the herbicides used previously; the Figure shows only a few of the latter.

infestation with weeds is greatest. Ideally, the different heterogeneity factors need to be separated before establishing the effects of using HT varieties (Heimlich, 2000; FernandezCornejo and McBride, 2002; Bonny and Sausse, 2004). It is also necessary to have access to detailed data on the herbicides applied. In the USA, different statistical sources exist in this area, but they rarely allow a comparison of the use of herbicides on transgenic and conventional soybean. Admittedly, sample surveys are carried out each year with farmers on the main crops in order to evaluate the use of fertilisers and pesticides (USDA NASS, 1991-2007). But these surveys establish this use globally per crop without separating their use on GM and non-GM soybean. Nevertheless, the use on the two types could be evaluated for the rare years where more detailed surveys were carried out by the USDA, the ARMS (Agricultural Resources Management Surveys). However, it would necessary to have access to the survey's detailed individual documents, which was not possible. The only access to differentiated results for GM and non-GM soybean was for 1997-98, where a detailed analysis was carried out by the USDA services; but this concerns only the very first years of HT soybean. Thus, the trends in the use of herbicides were studied globally for the soybean acreage by using the annual USDA survey on this topic (USDA NASS, 1991-2007).

These USDA surveys on the herbicides used are sample surveys concerning most of the soybean-producing states, but with a variable number of states, depending on the year. The surveys always include the major soybean-producing states, but the number included of states producing low quantities varies depending on the year. To eliminate these variations, we have brought the herbicides used back to the total surface of soybean included in the survey each year, thus establishing the mean doses of herbicides per ha. The values can be compared from one year to the next as the states that are not surveyed grow low quantities and so have rather little influence on the average. However, given the sampling variation from one year to the next, these doses of herbicide per global ha of GM and non-GM soybean must be considered cautiously: these are approximate evaluations.

\subsection{Rapid growth in the use of glyphosate progressively replacing a large majority of former herbicides}

The trends in soybean treatments from 1990 to 2006 show that the progression in HT varieties leads to a progressive substitution of many herbicides formerly used with glyphosate (Fig. 1). In particular, imazethapyr, trifluralin, imazaquin and pendimethalin were widely used in 1995, and much less in 2006. Thus, from 1995 to 2006 the percentage of soybean acreage treated with imazethapyr decreased from $44 \%$ to $3 \%$, and the percentage treated with pendimethalin decreased from $26 \%$ to $3 \%$.

What has the evolution in the number of herbicide treatments been? Before HT varieties, in 1995, soybean received approximately 2.7 herbicide treatments. The use of transgenic soybean has allowed the number of treatments to be reduced (Heimlich et al. 2000; Benbrook, 2004; Brookes and Barfoot, 2005; Fernandez-Cornejo and Caswell, 2006). This reduction is difficult to evaluate considering the diversity in weeding practices as well as the fact that glyphosate is (and was already in 1996) also used with non-transgenic varieties, notably in the case of no till: the available statistics do not allow distinction between the different types of use. USDA surveys show a decrease in the number of treatments from 1996 to 2001; 
thereafter, a near stagnation at approximately 1.9 treatments, then a slight increase in 2006 (2.1 treatments).

In terms of the quantity of herbicides used over a given surface area of soybean (Fig. 2), that of glyphosate has of course increased due to the rapid expansion of the transgenic varieties that represented $89 \%$ of all soybean in 2006 . There also seems to have been a slight increase in the number of glyphosate treatments per ha of soybean treated over the last few years. The total quantity of herbicides spread over soybean initially decreased from 1996 to 2001, but seemed to undergo two quite marked increases in 2002 and 2006. In this way, globally, on a given surface area of soybean, the total level of herbicide use in 1996 seems to have been reached again in 2005 and overtaken in 2006 (Fig. 2). However, we cannot deduce from these observations that compared with conventional soybean, HT soybean requires less herbicide in the first years, but then more, since other factors intervene in the evolutions of herbicides used. Other than the possible effects of weather variations, these particularly include the development of conservation tillage (CT) and the drop in herbicide prices.

Indeed, with CT, as weeds can no longer be controlled by being buried during ploughing, an increase in the use of herbicides is quite often observed. As for price, the diffusion of HT soybean having brought about the replacement of certain formerly used weedkillers by glyphosate, the agro-chemical firms that produced them have markedly decreased their prices since 1996 to limit market losses and stay competitive (Fig. 3). This has induced a global reduction in herbicide treatment costs for all soybean producers whether they use transgenic varieties or not (Lemarié, 2000; Bullock and Nitsi, 2001). This drop in herbicide prices may have contributed to a certain increase in the quantities used. As for seeds, their price has increased over the years, meaning that in soybean production costs, the seed cost has increased while that of herbicides has dropped (Fig. 3). However, overall, between 1995 and 2006, the share of the seeds + herbicides cost has varied relatively little in the total production costs of soybean.

\subsection{Environmental impacts}

As indicated previously, the quantity of weedkiller alone would not be a valid indicator of its effect on the environment. It is necessary to balance each herbicide with indicators that take into account its environmental and toxicological impacts. Numerous parameters and indicators exist on the matter, assessing herbicide impacts on human health, animal health, various organisms (bees, birds, mammals, etc.) and several environments (soil, water, etc.). The use of composite indicators elaborated using combinations of basic indicators is necessary in order to carry out global evaluations: through different methods they aggregate the various data on the toxicity and ecotoxicity of each pesticide (Devillers et al., 2005). However, these composite indicators are numerous: more than 42 indicators have been listed by Devillers et al. (2005). Amongst them, the EIQ, Environmental Impact Quotient, perfected by Kovach (1992), was used here. It simultaneously takes into account three important aspects: effects on workers, effects on

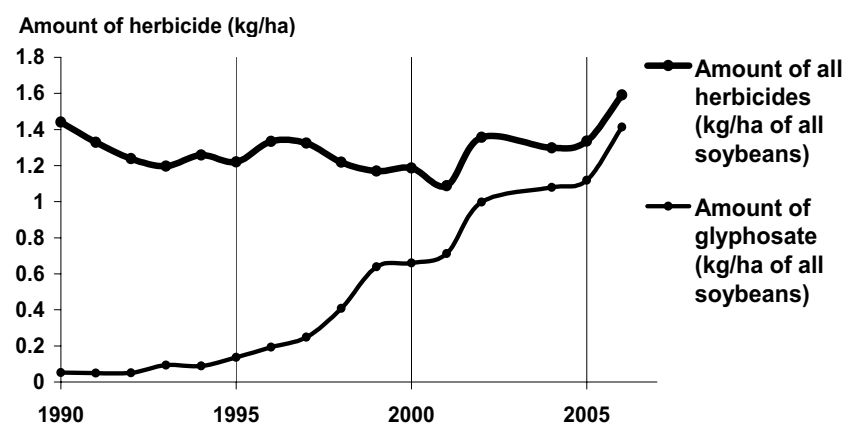

Figure 2. Quantity of herbicides, and in particular of glyphosate, on total US soybean acreage, 1990-2006. With the rapid expansion of transgenic soybean from 1996, the quantity of glyphosate used increases as it replaces the other herbicides. The total quantity of herbicide spread decreases between 1996 and 2001, but then increases in a non-continuous manner. This can be explained by different factors. NB. The quantities of herbicides used have been brought back to the total acreage of soybean to eliminate the effect of variations in the overall soybean surface area, but the values are approximate due to sampling error. Source: calculations of the author based on USDA NASS (1991-2007).

consumers and water, and ecological effects, and could be applied to the majority of herbicides spread on soybean. For its calculation, the different effects of herbicides are established on the basis of toxicity parameters related to the applicators and agricultural workers on the one hand, to consumers and leaching on the other, and finally to fish, birds, bees, beneficial insects and soil organisms. Regarding its calculation method, the higher the EIQ, the higher the environmental impact, i.e. the more toxic the herbicide is considered to be.

The EIQ was here established for each herbicide used on soybean, then overall for all herbicides used annually by multiplying the amount of each herbicide used per ha by its EIQ, and by then adding the values. So, for each year we assess the field EIQ value of all soybean herbicides, a kind of environmental footprint of these herbicides. This impact indicator decreased from 1994-1996 (29.15) to 2001 (20.4), but tends to slightly increase in 2002 (23.8) and 2006 (25.7). The toxicity of the herbicides used, considered overall, seems therefore to have decreased with the adoption of GM crops. But this diminution tends to subside after several years, and particularly in 2006 as the quantities spread increase. Other work using another indicator or analysing different HT crops over less than 10 years also obtained a decrease in the level of toxicity of the herbicides applied (Nelson and Bullock, 2003; Gardner and Nelson, 2007b; Brookes and Barfoot, 2005).

\subsection{Appearance of glyphosate-resistant weeds}

The significant increase in the use of glyphosate has diverse causes in addition to the rapid progression of herbicidetolerant crops (Woodburn, 2000). The glyphosate patent expired in September 2000 in the USA (in 1991 in some other countries), generics developed and competition between firms 


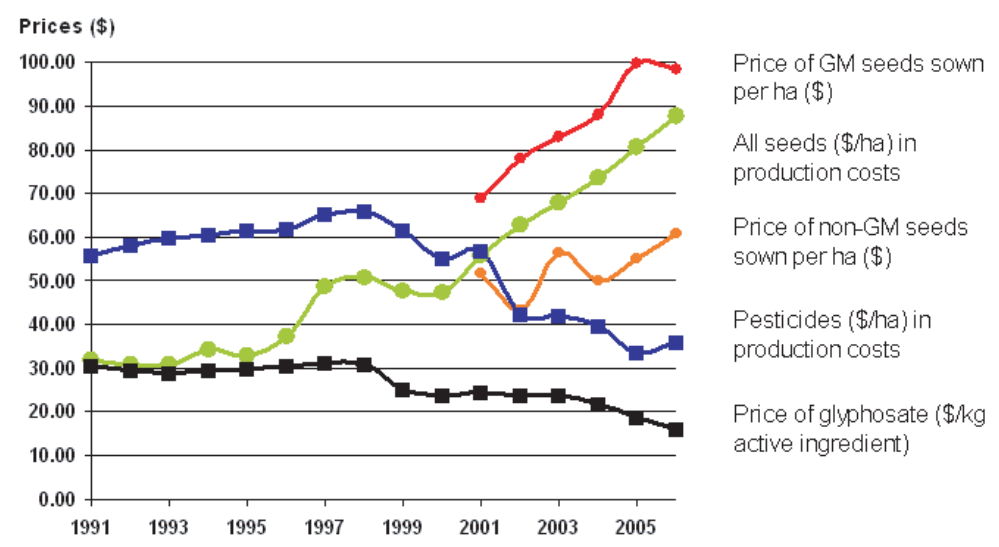

Figure 3. Price of glyphosate ( $\$ / \mathrm{kg}$ of active ingredient), price of GM seeds and non-GM seeds sown per ha (\$) and costs of pesticides and seeds in soybean production costs per ha, 1991-2006 (the seed price is the price for the mean seed dose used for soybean). Source: author's calculations from USDA NASS (1992-2007) and from USDA ERS (2007b).

was fierce, especially as it concerned the most popular herbicide. Furthermore, Monsanto sought to increase its sales as they provided it with liquid assets while it was investing heavily in research and the acquisition of seed companies. High glyphosate gross profit was essential for Monsanto so long as that of its other sector (seeds and genomics) was still in the early stages of development. The increased use of glyphosate, whether Monsanto's Roundup or generic versions, notably took place through HT plants, non-agricultural consumption, or conservation tillage. The statistics of the Environmental Protection Agency (EPA) show that in the USA, the annual use of glyphosate in thousands of tonnes of active ingredient increased from 3.2 in 1987, to 16.3 in 1997, to 32 in 1999, and nearly 50 in 2001, taking into account all uses, including agricultural and others. Glyphosate for agricultural use increased from 3,000 tonnes in 1987 to 40,000 tonnes in 2001, a thirteen-fold multiplication in 14 years (Aspelin and Grube, 1999; Donaldson et al., 2002; Kiely et al., 2004).

This high increase in the use of glyphosate - formerly spread on much smaller areas - has led to the appearance of weeds resistant to this herbicide (Heap, 2007; Owen and Zelaya, 2005; Cerdeira and Duke, 2006). Glyphosate-resistant weeds have already appeared in the USA in different states (eight weeds at mid-2007), as well as elsewhere in the world (thirteen weeds in total at mid-2007). This emergence was very predictable because of the high selective pressure for weeds, even if certain properties of glyphosate have slowed this in comparison with other herbicides that have known a similar phenomenon (Service, 2007). This partial loss in glyphosate's efficiency is considered prejudicial, as it will have to be supplemented or replaced by other herbicides that are generally more noxious and difficult to use compared with glyphosate: hence, there is a risk of loss on a global environmental level (Service, 2007; Marsch et al., 2006). In this way, the present substantial expansion in the use of glyphosate may prove to be disadvantageous in the medium term, not so much for Monsanto, whose main sales are now transgenics and genomics, but above all globally.
Thus, the total quantity of herbicide used on soybean initially decreased, but then seems to rise in 2002, and especially in 2006, overtaking the previous levels. Nonetheless, the environmental assessment of HT soybean development using a composite indicator improves somewhat. But what will its evolution be in the years to come? It is necessary to continue the analysis to examine how the total quantities of herbicide and the environmental impact indicator evolve, especially since glyphosate-resistant weeds have appeared and other types of HT crops are likely to be placed on the market.

\section{SOME TECHNOLOGICAL PROSPECTS OF TRANSGENIC SOYBEAN OVER THE NEXT FEW YEARS}

For 12 years, one trait introduced by transgenesis was dominant in GM soybean, and among all transgenics: Monsanto's herbicide tolerance. Will new traits be diffused over the years to come? This seems probable. Indeed, the big companies, Monsanto, Syngenta, Dupont/Pioneer, Bayer, BASF and Dow, that have actively invested in transgenics, continue their research while being engaged in fierce competition. On the one hand, other glyphosate-tolerant crops, in addition to soybean, corn, cotton and canola, will most certainly be marketed in the USA, even though this is sometimes the subject of heated debate due to fears of losing a share of the export market. Indeed, HT wheat, which was on the point of being commercialised in 2004, was not in the end, to avoid a decrease in purchases by different countries. On the other hand, concerning soybean, Monsanto is preparing a new generation of HT soybean: the "Roundup RReady2Yield" soybean, which should have a better yield as well as being glyphosate-tolerant; and also a new type of soybean tolerant to another herbicide, Dicamba (Monsanto, 2007; Service, 2007; Hinsch, 2006; Steiner, 2006).

Firms other than Monsanto envisage commercialising other glyphosate tolerance traits, notably the GAT system, Glyphosate ALS (acetolactate synthase) Tolerance, by 
Pioneer/DuPont, and for corn, Agrisure Glyphosate Tolerance by Syngenta. Tolerance to another herbicide, imidazolinone, has also been developed in soybean by BASF and EMBRAPA (Empresa Brasileira de Pesquisa Agropecuária, Brazilian Agricultural Research Corporation). However, in the USA, the proportion of HT soybean should hardly increase in the years to come as it is close to the maximum.

In addition, for soybean, the companies involved are working on different composition modifications that may concern human or animal foodstuffs or processing, and on perfecting varieties tolerant to soybean cyst nematode or rust. A new soybean has been commercialised from 2006. As well as being glyphosate-tolerant, it has a slightly modified composition, with a lower concentration of linolenic acid in order to reduce trans-fatty acid formation during industrial processing. Although this trait was introduced using conventional genetic methods, the fact that it was inserted into HT soybean means that this new soybean (called Vistive) is transgenic. Other new traits in the soybean pipeline include a higher betaconglycinin content to improve taste and texture in products such as soy milk and meat alternatives as well as a higher stearidonic acid content to increase the quantity of functional omega3 fatty acids (Hinsch, 2006; Steiner, 2006). Work is also in progress on soybean for energy usage and its transformation into biodiesel. It is also probable that transgenics with two or three traits introduced simultaneously for different objectives ("stacked genes") will be diffused.

If the present and future developments envisaged for transgenic crops are compared with what was hoped for - or at least presented - more than a decade ago, there appears to be a gap in the realisation times. In 1994, Robert Fraley, currently chief technology officer at Monsanto, hoped for the development of "food processing" traits from the end of the nineties, followed by plants with modified composition for nutrition or health purposes as of the year 2000 (Fig. 4). These prospects are indeed still present, but have a more distant commercialisation date. The GMOs marketed since 1996 have sometimes been criticised for not responding to consumers' needs, but only to those of certain farmers. Some companies, aware of this, now present their future developments in terms of their potential interests for farmers, consumers and processors (Tinland, 2007). And traits such as drought resistance, with a much more obvious potential interest than herbicide tolerance, are clearly in the pipeline for firms.

Finally, it must be noted that the transgenic character of American soybean has not brought about any lasting serious difficulties for exports, contrary to what is sometimes thought. Indeed, world soybean imports have increased and are projected to rise. However, imports of north-American origin that were formerly predominant have been and should be increasingly surpassed, notably by imports from Brazil where GM soybean is also expanding (Fig. 5). This is particularly the result of the production increase in South America, especially as production costs are lower than in the USA, notably because of lower land prices. As the Asiatic market grows, outlets are opening for GM soybean, as well as for non-GM soybean which has a preserved identity on specific markets, such as human foodstuffs in certain countries.

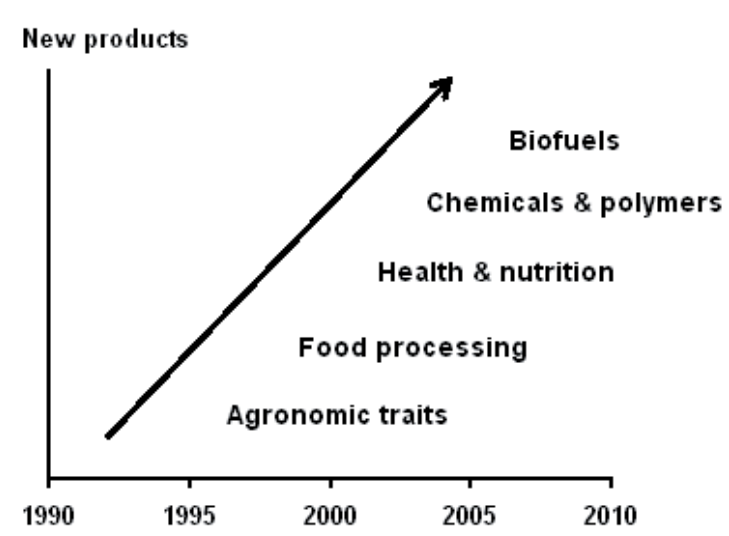

Figure 4. Development prospects for new products using agbiotechnology in the next 15 years, as anticipated in 1994 by Fraley (From Fraley, 1994, modified). These prospects are still present, but have a more distant commercialisation date.

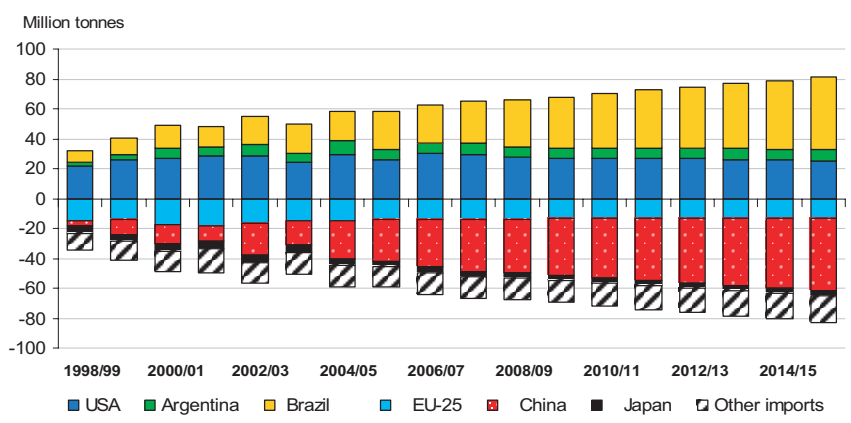

Figure 5. Evolution and forecast of world trade in soybean grain, 1998/99-2015/16. Exports are represented above the abscissa, imports below; trade in soybean meal is not taken into account here. The increase in the proportion of transgenic soybean (30\% in 1999, 64\% in 2006 at world level) does not affect the demand. The leadership of the USA in export diminishes faced with the expected growth of Brazilian exportations, also largely transgenic. Source: from FAPRI (Food and Agricultural Policy Research Institute), 2007.

\section{CONCLUSION}

\subsection{Herbicide-tolerant soybean: adoption factors and impacts on herbicide use}

In the USA, HT soybean spread rapidly and had a high adoption rate. There are different reasons behind this, including an institutional, economic and cultural context favourable to this innovation, its interest for farmers, support from numerous actors, and the vigorous Monsanto strategy. For farmers, HT soybean has agro-economic advantages compared with conventional soybeans: easier weed control management, greater application flexibility, no herbicide persistence, etc. HT and conventional soybean gross margins are frequently similar. The extra price of transgenic seed (technology fee) is normally offset by the reduced herbicide cost, even though there has been a trend towards a rise in transgenic seed prices 
over the years. In the short term at least, the advantages of HT soybean seem to override its disadvantages, such as more expensive seed, risk of difficulties in controlling volunteers if two HT crops tolerant to the same herbicide are planted in succession, etc. The economic appeal of HT soybean for farmers seemingly comes from the effects it brings, chiefly the simplified weedkilling process making more time available for other activities, and the good combination with conservation tillage that can thus be developed. This last point is also important from an environmental point of view as conservation tillage leads to significant reduction in soil erosion, to better carbon sequestration, to an increase in organic matter in the soil, etc.

As far as concerns the changing amounts of herbicides used, it is difficult to analyse changes linked to the development of HT soybean using the currently available statistics. Surveys carried out by the USDA on agro-chemicals applied every year establish the usage of various herbicides globally for each crop, without differentiating between HT or conventional varieties. Only global data are therefore available on changes in herbicide applications for all soybeans, with no possibility of comparing HT and conventional soybeans, or differentiating between the various uses of glyphosate (except for two years when there was an additional survey). In addition, the USDA surveys always include the major soybean-growing states, but not all the soybean-growing states, the number depending on the year. Thus, the herbicide amount used per hectare of soybean must be considered cautiously. Few, if any, standard, conventional herbicides are used on transgenic soybean, almost all having been replaced by glyphosate. But dose rates per hectare for conventional herbicides can vary widely, depending on the molecule. The change in herbicide quantities used in $\mathrm{kg} / \mathrm{ha}$ therefore varies tremendously depending on the herbicides applied previously. The assessment for the majority of US soybean suggests that the total quantity of herbicides applied per unit surface area decreased initially between 1996 and 2001, but tended to rise afterwards, although not steadily. A weight assessment of this type has little significance, however. To assess the environmental and toxicological impacts of herbicides, their quantity must be weighted by taking into account their conditions of application and their toxicity and ecotoxicity, using appropriate indicators. The calculation of such a composite indicator for herbicides used on all soybean shows that their environmental impact improved when the growth rate of the proportion of HT soybean was high. However, more recently there was a stagnation or a slight deterioration; nevertheless, the present environmental impact remains better than it was before 1996. But how will this trend evolve if more herbicides are used over the next few years? Herbicide consumption and its impacts must be monitored, especially as other HT plants exist and are likely to be placed on the market in the years to come.

Between 1996 and 2006, with the development of glyphosate-tolerant crops, this herbicide was used far more extensively as it gradually replaced the weedkillers used previously. This increase in the use of glyphosate is also based on its frequent association with conservation tillage and the drop in its price. But one knock-on effect of its extensive use has been the appearance and development of some weeds resistant to it. Nevertheless, the issue here is not really genetic engineering in itself, but rather the management and governance of this innovation.

\subsection{Assessment of the impacts of transgenic crops: methods and issues}

The impacts of GMOs having been the subject of many critical and controversial commentaries, it seems necessary to recall certain points. Firstly, the impacts of GMOs cannot be addressed globally and generally. Indeed, to evaluate transgenic crops, a case-by-case approach is necessary according to the transgene type and conditions of use, the possible alternatives for each situation, and the people concerned; it is also necessary to carry out multi-criteria assessments, integrating the context and evolution dynamics. Moreover, history has shown that innovations always evolve considerably between the first products and those developed afterwards, because of technical and scientific advances, general socio-economic evolutions and changes in context, and finally, the reactions of all those involved. So, we cannot judge GMOs in general solely on the basis of the GMOs widely diffused to date and the trees of the first GMOs must not hide the wood of biotechnology. Finally, the "technical impacts" are not determined a priori, they depend on how the innovation is directed, implemented, regulated and used in practice, and therefore on the economic, social, institutional and cultural context in which it is inserted. Therefore, the management and governance of the innovation and techniques are major factors; the expression "technical impacts" is thus hardly adequate.

At the beginning of the ' 80 s, biotechnology was presented as a new wave of innovations, a new technological paradigm, based on the better use and enhancement of life processes. It seemed likely to surpass some of the limits of the previous wave of innovations, relying namely on chemistry and fossil fuels. However, its birth and first years were difficult. The first widespread transgenic crops, those that are herbicide-tolerant, have, through this characteristic, often disappointed. In the '80s or the '90s, the potential of biotechnology to allow plants to be more "self-sufficient", not reliant, for example, on different pesticides, was often evoked. Yet HT plants, the most widespread at present, go hand in hand with the use of a herbicide, even if it is considered less noxious than others. The gap compared with the announcements made twenty years ago results from different economic or technical factors explaining the development of this type of GMO in the first place.

\subsection{The first decade of transgenic crops and its assessment}

The extension of transgenic crops is highly uneven, depending on the country. In France, GMOs have crystallised numerous oppositions, hence there is a strong blockage towards them. However, in addition to some French companies, it is above all public research that has in fact been slowed, which 
has indirectly increased what was feared: the monopolistic position and the domination of major international firms. This has led to a lack of investment in biotechnology applications that could be more geared towards the public good or beneficial for a greater number and for the environment, which in turn strengthens opposition.

The first transgenic crops developed in an economic context marked by the financialisation of the economy, leading the major companies to seek rapid profitability which was not always in line with certain sustainable development objectives that had been laid out. The major firms initially worked on traits such as herbicide tolerance as they were technically faster to identify and to transfer into quite a high number of species through genetic engineering, which enabled a relatively fast return on investment. In addition, the substantial investments made by certain chemical and agro-chemical companies which bought seed firms, and the context of heightened competition with the domination of extremely demanding financial markets, weakened certain firms and/or led to aggressive behaviour. This is perceived by part of the population as unethical and in contradiction with some of the objectives announced. More generally, are intense competition and the quest for fast, high profit dictated by the financial markets compatible with sustainable development objectives? Sustainable development does not solely rely on reducing pollution, but also on more harmonious economic and social relations, and on greater cooperation between the actors involved. Wouldn't biotechnology have more chance of developing and also being accepted if competition gave way to more cooperative behaviour, which does not depend on the biotechnology sector alone.

Acknowledgements: The author sincerely thanks all the persons interviewed for this work. This research work was supported in part by INRA (Action Incitative Programmée "OGM et environnement") and by the French Ministère de la Recherche (Action Concertée Incitative "impact des OGM dans les agro-écosystèmes").

\section{REFERENCES}

Agbios (2007) GM Crop Database. Agbios, Ontario, Canada 2007.

Alexander C. (2006) Framer decisions to adopt genetically modified corps. CAB Reviews: Perspectives in Agriculture, Veterinary Science, Nutrition and Natural Resources 1, N. 045, 9 p., DOI: 10.1079/PAVSNNR20061045.

ASA (American Soybean Association) (2001) Conservation Tillage Study, Saint-Louis (MO), Nov. 2001, 22p.

Ash M. (2001) Soybeans: Background and Issues for Farm Legislation, USDA-ERS report No. OSC-0701-01, July 2001, 9 p.

Aspelin A., Grube A.H. (1999) Pesticides Industry Sales and Usage: 1996 and 1997 Market Estimates, USEPA, Washington, Nov. 1999.

Barnes R.L. (2000) Why the American Soybean Association supports transgenic soybeans, Pest Manage. Sci. 56, 580-583.

Benbrook C.M. (2004) Genetically Engineered Crops and Pesticide Use in the United States: The First Nine Years, BioTech InfoNet, Technical Paper N. 7, Sandpoint, Idaho (USA), 53 p.

Bonny S. (2003) Why are most Europeans opposed to GMOs? Factors explaining rejection in France and Europe, EJB The Electron. J. Biotechnol. 6, 20-41.
Bonny S. (2005a) The Growth Of Transgenic Crops In The USA: What It Tells Us, INRA Sciences Sociales, English version, 2005/01, No. 4-5.

Bonny S. (2005b) Quelle place des cultures transgéniques en protection des plantes ? Aspects agro-économiques, in: Regnault-Roger C. (Ed.). Enjeux phytosanitaires pour l'agriculture et l'environnement, Paris, Éditions Tec et Doc Lavoisier, pp. 895-917.

Bonny S. (2007) How are opinions about GMOs changing over time? The case in the EU and the USA, Proceedings of the 16th International Plant Protection Congress, Glasgow (UK), BCPC, pp. 166-167.

Bonny S., Sausse C. (2004) Les cultures transgéniques permettent-elles de réduire l'usage des produits phytosanitaires ? Considérations à partir du cas du soja tolérant au glyphosate, OCL Oléagineux, Corps gras, Lipides 11, 85-91.

Brookes G., Barfoot P. (2005) GM Crops: The Global Economic and Environmental Impact - The First Nine Years 1996-2004, AgBioForum 8, 187-196.

Bullock D., Desquilbet M. (2002) The economics of non-GMO segregation and identity preservation, Food Policy 27, 81-97.

Bullock D., Nitsi E. (2001) Roundup Ready Soybean Technology and Farm Production Costs: Measuring the Incentive to adopt genetically modified seeds, American Behavioral Scientist 44, 12831301 .

Canadian Biotechnology Secretariat (2005) International Public Opinion Research on Emerging Technologies, A Canada - US Public Opinion Research Study on Emerging Technologies.

Carpenter J., Gianessi L. (1999) Herbicide Tolerant Soybeans: Why Growers are adopting Roundup Ready Varieties, AgBioForum 2, $65-72$.

Carpenter J., Gianessi L. (2000) Agricultural Biotechnology: Benefits of Transgenic Soybeans, NCFAP, Washington, April 2000, 105 p.

Carpenter J., Gianessi L. (2001) Agricultural Biotechnology: Updated Benefit Estimates. NCFAP, Washington, Jan. 2001, 48 p.

Carpenter J., Gianessi L. (2002) Case Study in Benefits and Risks of Agricultural Biotechnology: RR Soybeans, in: Santaniello V., Evenson R.E., Zilberman D. (Eds.), Market Development for Genetically Modified Food, Wallingford, CABI Publishing, pp. 227-243.

Cerdeira A.L., Duke S.O. (2006) The Current Status And Environmental Impact Of Glyphosate Resistant Crop: A Review, J. Environ. Qual. $35,1633-1658$.

CTIC (2004) National crop residue management survey, CTIC (Conservation Technology Information Center), West Lafayette (Indiana, USA) and USDA-NASS, Washington.

Devillers J., Farret R., Girardin P., Rivière J.L., Soulas G. (2005) Indicateurs pour évaluer les risques liés à l'utilisation des pesticides, Lavoisier, Tec\&Doc, 278 p.

Donaldson D., Kiely T., Grube A. (2002) Pesticides Industry Sales and Usage: 1998 and 1999 Market Estimates, USEPA, Washington, 2002.

Duke S.O., Ragsdale N.N. (2005) (Eds.) Special Issue: Herbicideresistant Crops from Biotechnology, Pest Management Science 61, 209-325.

Eurobarometer (2006) Europeans and biotechnology in 2005. Eurobarometer 64.3, Luxembourg, Office for Official Publications of the European Communities, Brussels, CE, DG Research. July 2006, 88 p.

FAO (2004) The State Of Food And Agriculture 2003-2004, Agricultural Biotechnology Meeting the needs of the poor? Rome, FAO 2004.

FAPRI (2007) US and World Agricultural Outlook 2007, Food and Agricultural Policy Research Institute, Iowa State University, Ames (Iowa, USA), 411 p. www.fapri.iastate.edu/outlook2007/.

Fernandez-Cornejo J., McBride W.D. (2002) Adoption of Bioengineered Crops. Agricultural Economic Report, No. AER810, Economic Research Service, USDA, Washington, 2002 www.ers.usda.gov/publications/aer810/aer810.pdf. 
Fernandez-Cornejo J., Caswell M. (2006) The First Decade of Genetically Engineered Crops in the United States, USDA ERS, Economic Information Bulletin (11), April 2006.

Fernandez-Cornejo J., Hendricks C., Mishra A. (2005) Technology Adoption and Off-Farm Household Income The Case of HerbicideTolerant Soybeans, J. Agr. Appl. Econ. 37, 549-563.

Foreman L., Livezey J. (2002) Characteristics and Production Costs of U.S. Soybean Farms. USDA-ERS Statistical Bulletin N SB974-4. April 2002.

Fraley R.T. (1994) Commercialization of Genetically Modified Plants: Progress Towards the Marketplace, in: Fessenden MacDonald J. (Ed.), Agricultural Biotechnology \& the Public Good, NABC (National Agricultural Biotechnology Council) Report 6, Ithaca, New York, pp. 33-41.

Gardner J.G., Nelson C.H. (2007a) Genetically Modified Crops and Labor Savings in US Crop Production, Paper presented at the 2007 Southern Agricultural Economics Association Annual Meeting, 4 7 February 2007, Mobile, Alabama, 20 p.

Gardner J.C., Nelson G.C. (2007b) Assessing the environmental consequences of glyphosate-resistant weeds in the US, 11th International Conference on "Agricultural Biotechnologies: New Frontiers and Products" organized by the International Consortium on Agricultural Biotechnology Research (ICABR), Ravello - Scala, Italy, July 2007.

Gianessi L.P., Silvers C.S., Sankula S., Carpenter J.E. (2002) Plant Biotechnology Current and Potential Impact For Improving Pest Management In U.S. Agriculture: An Analysis of 40 Case Studies, NCFAP (National Center for Food and Agricultural Policy), Washington, $32 \mathrm{p}$.

Gomez-Barbero M., Rodriguez-Cerezo E. (2006) Economic Impact of Dominant GM Crops Worldwide: a Review, European Commission, DG Joint Research Centre, Institute for Prospective Technological Studies. Luxembourg, Office for Official Publications of the EC, $48 \mathrm{p}$.

Heap I. (2007) International survey of herbicide resistant weeds, Herbicide Resistance Action Committee, and Weed Sci. Soc. Am. www.weedscience.org

Heimlich R.E. et al. (2000) Genetically Engineered Crops: Has Adoption Reduced Pesticide Use? Agricultural Outlook (USDA ERS), August 2000, 13-17.

Hinsch A. (2006) Soja de alto valor, Argentina perder el tren? 3er Congreso de Soja del Mercosur, Rosario (Argentina), 27-30 June 2006.

James C. (2007) Global Status of Commercialized Biotech/GM Crops: 2006, ISAAA Briefs N 35. ISAAA (International Service for the Acquisition of Agri-biotech Applications), Ithaca, NY.

Kalaitzandonakes N.G. (2003) The economic and environmental impacts of agbiotech: A global perspective, New York: Kluwer Academic/Plenum Publishers, 336 p.

Kiely T, Donaldson D, Grube A. (2004) Pesticides Industry Sales and Usage: 2000 and 2001 Market Estimates, U.S. Environmental Protection Agency, Washington, May 2004.

Knezevic S.Z., Evans S.P., Mainz M. (2003) Yield penalty due to delayed weed control in corn and soybean, Crop Manage., www.plantmanagementnetwork.org/pub/cm/research/2003/delay/.

Kovach J., Petzoldt C., Degni J., Tette J. (1992) A Method to Measure the Environmental Impact of Pesticides, New York Agricultural Experiment Station, New York's Food and Life Sciences Bulletin 139. Cornell University, Ithaca, NY, 8 p.

Lemarié S. (2000) Analyse économique du développement des cultures à base d'organismes génétiquement modifiés aux Etats-Unis, Volet 1: Le développement des OGM Agronomiques, INRA-SERD, Grenoble, $42 \mathrm{p}$.

Marra M.C., Piggott N.E., Carlson G.A. (2004). The Net Benefits, Including Convenience, of Roundup Ready@ Soybeans: Results from a National Survey, NSF Center for Integrated Pest Management, Technical Bulletin 2004-3, Raleigh, NC, 40 p.
Marsch p., Llewellyn R., Powles S. (2006) Social Costs of Herbicide Resistance: the Case of Resistance to Glyphosate, Paper presented at the 50th Annual Conference of the Australian Agricultural and Resource Economics Society, Sydney, NSW, Australia, 8-10 February 2006.

Monsanto (2003) Executive Presentation to Members of the Financial and investment Community, Spring 2003 investor meetings. 12 May 2003.

Monsanto (2006) 2006 Annual report, Saint Louis (Missouri, USA), $128 \mathrm{p}$.

Nelson G.C. (2001) (Ed.) Genetically Modified Organisms in Agriculture, Economics and Politics, Academic Press, London, $344 \mathrm{p}$.

Nelson G.C., Bullock D.S. (2003) Simulating a relative environmental effect of glyphosate-resistant soybeans, Ecol. Econ. 45, 189-202.

Owen M.D.K. (2007) Genetically modified crops: successes and problems in the Midwest USA, Proceedings of the 16th International Plant Protection Congress, Glasgow, 2007, BCPC, pp 506-507.

Owen M.D.K., Zelaya I.A. (2005) Herbicide-resistant crops and weed resistance to herbicides, Pest Manage. Sci. 61, 301-311.

Sankula S., Marmon G., Blumenthal E. (2005) Biotechnology derived crops planted in 2004. Impacts on US agriculture, NCFAP (National Center for Food and Agricultural Policy), Washington, $101 \mathrm{p}$.

Sanvido O., Romeis J., Bigler F. (2007) Ecological impacts of genetically modified crops: ten years of field research and commercial cultivation, Adv. Biochem. Eng. Biotech. 107, 235-278.

Service R.F. (2007) A Growing Threat Down on the Farm, Science 316, $114-117$.

Steiner J. (2006) Innovating for the Future: World Trends, Seed Traits and Crop Inputs, Presentation at Minnesota Crop Production Retailers, 5 Dec. 2006.

Tinland B. (2007) Monsanto and Renessen's pipeline products, Presentation at EFSA (European Food Safety Autority) GMO scientific hearing with applicants, 21 March 2007.

UIUC (1999) Illinois Agronomy Handbook 1999-2000, University of Illinois, College of Agricultural, Consumer and Environmental Sciences, Urbana-Champaign, 245 p.

US GAO (2000) Information on prices of genetically modified seeds in the United States and Argentina, US General Accounting Office, Washington, $25 \mathrm{p}$.

USDA ERS (2007a) Adoption of Genetically Engineered Crops in the U.S. Data sets, USDA Economic Research Service. http://www.ers.usda.gov/Data/BiotechCrops/. July 2007.

USDA ERS (2007b) Commodity Costs and Returns, USDA Economic Research Service http://www.ers.usda.gov/Data/CostsAndReturns/.

USDA NASS (2000 to 2007) Acreage. Crop Production Supplement, USDA, National Agricultural Statistics Service, Washington, Annual publication, June.

USDA NASS (1992 to 2007) Agricultural Prices, Annual publication from USDA National Agricultural Statistics Service, Washington DC, USA, April.

USDA NASS (1991 to 2007) Agricultural Chemical Usage. 1990 to 2006 Field Crops Summary, Annual publication from USDA Economics, Statistics and Market Information System, Albert R. Mann Library, Cornell University, USA.

Wesseler J.H.H. (2005) (Ed.) Environmental Costs and Benefits of Transgenic Crops, Springer, Dordrecht, 280 p.

Woodburn A.T. (2000) Glyphosate: production, pricing and use worldwide, Pest Manage. Sci. 56, 309-312.

Worldviews (2002) Worldviews 2002: American and European Public Opinion on Foreign Policy, Chicago Council on Foreign Relations, The German Marshall Fund of the US. 